\title{
Putting a Price on Natural Capital
}

The first person I ever ran into who was interested in putting a value on natural capital was Richard Brautigan, the whimsical writer who imagined the following conversation about a trout stream that was "for sale" at the Cleveland Wrecking Yard in his beloved San Francisco:

"'How much are you selling the stream for?' I asked.

'Six dollars and fifty-cents a foot,' he said. 'That's for the first hundred feet. After that it's five dollars a foot.'

'How much are the birds?' I asked. 'Thirty-five cents apiece,' he said. 'But of course they're used. We can't guarantee anything.'

'What kind of animals do you have?' I asked.

'We only have three deer left,' he said.

"Oh...What about flowers?'

'By the dozen,' he said." (1967, Trout Fishing in America).

These days I'm reading slightly more sophisticated books and articles-writings in which people really believe they can, and must, put a price on natural capital. For example, Robert Costanza and his colleagues in their oft-cited 1997 article that established the annual average value of the world's natural capital at, at least, $\$ 33$ trillion: "So, although ecosystem valuation is certainly difficult and fraught with uncertainties, one choice we do not have is whether or not to do it. Rather, the decisions we make as a society about ecosystems imply valuation (although not necessarily expressed in monetary terms)" (p. 255, Nature 387).

With the work of environmental economists such as Costanza, Herman Daly, Annmari Jansson, Thomas Prugh and others in hand, various organizations and policymakers have been trying on the idea of valuing natural capital and determining ways to account for it. Likewise, some restorationists-James Aronson and Andy Clewell arguably being the most prominent-have begun to emphasize the connection between natural capital and ecological restoration, and between environmental economists and ecosystem restorationists. This issue of Ecological Restoration contains a report by Aronson, Sue Milton, and James Blignaut about a workshop that was held in late October 2005 to explore those connections, and the possibilities and barriers that we face in accurately accounting natural capital, and the role restoration can play in making the world a more sustainable place.

I'm not going to spend much time here discussing what happened at that meeting. I wasn't there, so all I know is what I've read in their article and what I've learned by talking to a few people who did attend. I will say this, however, while I applaud the concept and the work that James and others are doing, I remain puzzled by the apparent lack of practical discussion about why and how ecological restorationists should and could provide economists with the costs of restoring damaged natural and cultural ecosystems.

Just imagine the work that is already taking place inside companies that do restoration-related projects. Someone or a group of people are figuring out costs, making estimates, compiling budgets, and pouring over spreadsheets. Numbers are everywhere. Others are gathering data from local people about their interest in the environment and support for restoration projects. Similar work goes on in federal, state, and local organizations and agencies.

Environmental economists use a variety of methods to determine the dollar-based value of ecosystems: 1) market price; 2) productivity; 3) hedonic pricing; 4) travel costs; 5) damage cost avoided, replacement cost, substitute cost; 6) contingent valuation; 7) contingent choice; and 8) benefit transfer (see www. eco systemvaluation.org). After considering each of these methods, it seems to me that cost information from restoration projects can provide data to economists for use in the last four methods, and likely in the productivity method as well.

One highly visible example of an agency that is creating data about replacement costs is the National Oceanic and Atmospheric Administration's Damage Assessment and Restoration Program (DARP), which was created after the 1989 Exxon Valdez oil spill. They have developed a Habitat Equivalency Analysis for determining 1) the cost of restoring the resource to pre-injury conditions, 2) compensation for any interim loss of resources until the resource is restored, and 3) the reasonable cost of performing the damage assessment. From 1990 to 2002, DARP processed numerous cases and had obtained $\$ 300$ million for restoration purposes.

Ecological restoration is a fledgling enterprise, it's true, but I sense that it's time for those who have information about the costs of their projects to share it - anonymously or otherwise- - with environmental economists directly. Or, alternatively, with an organization (perhaps SER International in affiliation with the International Society for Ecological Economics) that would develop a database of restoration costs for damaged natural and cultural ecosystems. That effort might just be the bond that finally ties economics and ecology together.

Oh, by the way, I'm sure you're wondering about Brautigan's stream and its insects-no stream is complete without them. "The insects we're giving away free with a minimum purchase of ten feet of stream."

Dave Egan 